\title{
THE RIGHT TO COUNSEL DENIED: RECENT CASES ON SECTION 10(b) OF THE CHARTER'
}

\author{
BRUCE P. ELMAN*
}

\section{INTRODUCTION}

Much of the pre-Charter law on the Right to Counsel was fashioned from cases arising out of what might loosely be termed breathalyzer litigation. ${ }^{2}$ It is not surprising, therefore, that one of the most controversial issues raised since the advent of the Canadian Charter of Rights and Freedoms is whether a motorist who is stopped by a police of ficer and required to accompany the of ficer for the purposes of giving a sample of breath for a breathalyzer test is entitled to be informed of his right to retain and instruct counsel. The central question is whether a person who is given such a demand (i.e. a demand under section 235 of the Criminal Code) and accompanies the police officer for the purpose of taking the test is "arrested" or "detained" within the meaning of section 10 of the Charter. ${ }^{3}$ Further, this issue involves a reconsideration of Chromiak v. The Queen. ${ }^{4}$ This matter is dealt with in the recent Alberta Court of Appeal decision of Rahnv. The Queen ${ }^{5}$ and the companion cases of Engen v. The Queen ${ }^{6}$ and The Queen v. Campbell.'

\section{THE FACTS IN RAHN V. THE QUEEN}

The facts arising in the Rahn case are totally unremarkable. At 4:31 on the morning of July 31,1982 , the accused was observed by a R.C.M.P. constable in care and control of a parked motor vehicle on a highway near Stony Plain, Alberta. The constable observed the usual signs of impairment and, consequently, read the accused a demand pursuant to section 235 of the Criminal Code that the accused accompany the constable for the purpose of providing a sample of his breath suitable for analysis in a breathalyzer machine. The constable failed to advise the accused that he had the right to retain and instruct counsel. The accused agreed to ac-

* Of the Faculty of Law, University of Alberta, Edmonton.

1. CONSTITUTION ACT, 1982.

2. See for example, Brownridge v. The Queen [1972] S.C.R. 926, 18 C.R.N.S. 308; Hogan v. The Queen [1975] 2 S.C.R. 574, (1975) 48 D.L.R. (3d) 427, 18 C.C.C. (2d) 65; Jamaga v. The Queen (1976) 29 C.C.C. (2d) 269 (S.C.C.); and Chromiak v. The Queen (1979) 49 C.C.C. (2d) 257 (S.C.C.), (1980) 12 C.R. (3d) 300. These cases were argued under section 2(c) (ii) of the Canadian Bill of Rights R.S.C. 1970. Appendix IIl as amended by S.C. 197071-72, c. 38, s.29 which states:

2. (No) law of Canada shall be construed or applied so as to ... (c) deprive a person who has been arrested or detained ... (ii) of the right to retain and instruct counsel without delay....

3. Section 10 of the Charter provides:

Everyone has the right on arrest or detention ... (b) to retain and instruct counsel without delay and to be informed of that right; and (c) to have the validity of the detention determined by way of habeas corpus and to be released if the detention is not lawful.

4. Supra n. 2.

5. (1984) 29 A.L.R.(2d) 289,50 A.R. 43 (Alta. C.A.).

6. (1984) 29 A.L.R.(2d) 304, 50 A.R. 51 (Alta. C.A.).

7. (1984) 29 A.L.R.(2d) 307,50 A.R. 54 (Alta. C.A.). 
company the constable and was placed in the back seat of the police car. The back seat of the police car had no inside handles; therefore, the accused could not have left the police car of his own accord. Subsequently, the accused gave two samples of breath for the breathalyzer. The readings were 130 and 120 milligrams of alcohol per 100 millilitres of blood. The accused was arrested, signed a promise to appear, and was released.

At trial, His Honour Provincial Court Judge Enright held that the accused had not been detained as a result of the breathalyzer demand. In the alternative, Judge Enright determined that, even if the accused had been detained, the admission of the evidence of the breath test readings would not bring the administration of Justice into disrepute. He therefore, admitted the evidence of the readings and convicted the accused.

The material facts in Campbell and Engen were essentially the same as those in Rahn. In Engen, however, it should be noted that while taking the accused for the breathalyzer test, the R.C.M.P. constables searched him.

All of these cases found their way to the Alberta Court of Appeal. All the cases were decided alike. The decision given in Rahn serves as the reasons for the decisions in all of the cases.

\section{THE DECISION IN RAHN V. THE QUEEN}

In Rahn, Mr. Justice Laycraft, speaking for himself and Justices McLung and Lieberman, held that an individual who is given a demand under section 235 of the Criminal Code and accompanies a police officer for the purpose of taking a breathalyzer test is not "arrested" or "detained" within the meaning of section 10 of the Canadian Charter of Rights and Freedoms. This was so, according to the court, in spite of the fact that the accused was taken at 4:30 a.m. and placed in the back section of a police car, this section having no inside door handles.

In reaching his decision, Justice Laycraft relied heavily on the Supreme Court of Canada decision in Chromiak v. The Queen. ${ }^{8}$ In that case, the accused was charged with failure to provide a sample of his breath suitable for testing in a roadside screening device, contrary to section 234.1(2) of the Criminal Code. He argued that no conviction should be entered because he was denied his right to retain and instruct counsel as provided for in section 2(c)(ii) of the Canadian Bill of Rights. In rejecting the defendant's contention, the Supreme Court of Canada relied upon the obiter comments of Mr. Justice Pigeon in Brownridge v. The Queen. ${ }^{9}$ In that case Justice Pigeon stated the following: ${ }^{10}$

The legal situation of a person who, on request, accompanies a peace of ficer for the purpose of having a breath test taken is not different from that of a driver who is required to allow his brakes to be inspected or to proceed to a weighing machine ... Such a person is under a duty to submit to the test. If he goes away, or attempts to go away. to avoid the test, he may be arrested and charged but this does not mean that he is under arrest until this happens. He is merely obeying directions that police of ficers are entitled

8. Supran. 2.

9. Id.

10. Id. at 18 C.R.N.S. 308 at 321. 
to issue. Motorists cannot reasonably expect to be allowed to seek legal advice before complying with such orders. Police of ficers are fully justified in treating as a definitive refusal a refusal to comply until legal advice is obtained.

These obiter comments form the cornerstone of the Court's decision in Rahn.

\section{ANALYSIS}

\section{A. THE CHROMIAK CASE AS PRECEDENT}

Three problems are attendant in treating the Chromiak case as binding on the Alberta Court of Appeal in Rahn. The first is that the Chromiak decision is based upon the judgment of Justice Pigeon in the Brownridge case. It must be noted that Justice Pigeon's judgment was a dissenting judgment in which no other member of the Court concurred. Further it should be remembered that Brownridge involved a very different set of facts. Finally, Justice Pigeon's statement that "Motorists cannot reasonably expect to be allowed to seek legal advice before complying with such orders" indicates that his decision was based upon a policy rationale akin to what might be argued under section 1 of the Charter, i.e. these are reasonable limits on the right to counsel. Section 1 of the charter provides:

The Canadian Charter of Rights and Freedoms guarantees the rights and freedoms set out in it subject only to such reasonable limits prescribed by law as can be demonstrably justified in a free and democratic society.

Two points should be noted in regard to this. First, the burden of proof in a section 1 argument would be on the Government to justify the detention rather than upon the defendant to show that a detention existed. Second, very different considerations might pertain if the govenment was seeking to justify section 235 (breathalyzer demand) rather than section 234.1 (demand in relation to a roadside screening device). Thus it might be argued that the Chromiak case is founded upon questionable precedent.

Secondly, the Chromiak case involved a refusal to comply with a demand in regard to a roadside screening device not a breathalyzer test. This distinction was noted by Mr. Justice Tallis of the Saskatchewan Court of Appeal in Regina v. Therens. "The person confronted by a demand to submit to a roadside screening test incurs no criminal or civil liability as an immediate and direct result of taking the test although he is criminally liable if he refuses the test. On the other hand, the motorist confronted with a breathalyzer demand may face serious problems of criminal and civil liability as a direct result of taking the breathalyzer test. Legal advice, Justice Tallis argues, is crucial at this stage of the proceedings. Justice Tallis states; ${ }^{12}$

Legal advice at this crucial stage is important when it comes to dealing with even the most basic questions such as whether or not the subject must comply with the demand and the consequences if he does not. Questions such as whether or not reasonable and probable grounds exist and the time frame for the tests warrant professional legal ad-

11. (1983) 33 C.R.(3d) 204 at 219 - 20. Leave to appeal to the Supreme Court of Canada was granted on June 6, 1983.

12. Id. at 219-20. 
vice. If a person may be subjected to criminal prosecution or penalties, or deprived of his operator's licence under provincial legislation or adversely affected in some other way such as loss of statutory insurance coverage, then the right to counsel imports the right to advice on these complex issues as soon as possible after the making of the demand.

Although this argument is rejected by Justice Laycraft, ${ }^{13}$ it might be argued that the differences in the direct consequences attendant the two tests provides a rational basis for distinguishing the Chromiak case.

Thirdly, it must be remembered that the Chromiak case detailed preCharter rights. It involved the Canadian Bill of Rights, a statutory instrument, rather than the Charter, a constitutional document. At no time in its history did the Canadian Bill of Rights attain a position of supremacy as is provided for the Charter in section 52 of the Constitution Act, 1982. Further it should be noted that section 2(c)(ii) of the Canadian Bill of Rights provides for "the right to retain and instruct counsel without delay". On the other hand, section 10(b) of the Charter provides for the right to "retain and instruct counsel without delay and to be informed of that right". (Emphasis added) In providing for an expansion of the right to counsel by including in it the right "to be informed of that right", the drafters of the Charter, it might be argued, have provided for a new right and indicated a break with the pre-Charter jurisprudence on the right to counsel. Finally, it is important to remember that Constitutions are to be interpreted differently than ordinary statutes. In Edwards v. A.G. Canada, ${ }^{14}$ Lord Sankey, in construing the then, British North America Act, stated:15

The British North America Act planted in Canada a living tree capable of growth and expansion within its natural limits. The object of the Act was to grant a constitution to Canada....

Their Lordships do not conceive it to be the duty of the Board - it is certainly not their desire - to cut down provisions of the Act by a narrow and technical construction, but rather to give it a large and liberal interpretation. (emphasis added)

In Minister of Home Affairs v. Fisher, ${ }^{16}$ the Privy Council, in considering the Bermuda constitution, questioned whether the "provisions are to be construed in a manner and according to rules which apply to Acts of Parliament". In rejecting this notion, Lord Wilberforce stated:17

\footnotetext{
In their Lordships view there are two possible answers to this. The first would be to say that, recognizing the status of the Constitution as, in ef fect, an Act of Parliament, there is room for interpreting it with less rigidity, and greater generosity, than other Acts ... The second would be more radical; it would be to treat a constitutional instrument such as this as sui generis, calling for principles of interpretation of its own, suitable to its character as already described, without necessary acceptance of all the presumptions that are relevant to legislation of private law.

... their Lordships prefer the second. (emphasis added)
}

Lord Wilberforce goes on to say that there are rules of law that should be applied to the interpretation of a constitution and that respect must be paid to the language used and its traditional meaning. He concludes by stating that the courts must recognize the character and origin of the in-

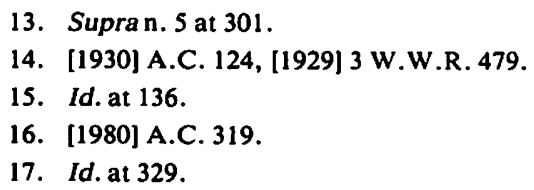


strument and must "be guided by the principle of giving full recognition and effect to those fundamental rights and freedoms with a statement of which the Constitution commences"'. ${ }^{18}$

The statements of Lord Sankey in the Edwards case and Lord Wilberforce in Fisher were endorsed by Mr. Justice Prowse of the Alberta Court of Appeal in Southam Inc. v. Hunter. ${ }^{19}$ Consequently, it might be argued that Chromiak is distinguishable as being pre-Charter jurisprudence.

Furthermore, one should be wary of using the Chromiak case as predictive of any future Supreme Court decision on this topic. It should be remembered that only seven judges participated in the decision. The late Chief Justice Laskin and Mr. Justice Dickson took no part in the decision in that case. Further, Mr. Justice Martland and Mr. Justice Pigeon have both retired from the Court and been replaced by Madame Justice Wilson and Mr. Justice Lamer. This reality leaves the final meaning of "arrest or detention" in breathalyzer cases in an uncertain state.

\section{B. OTHER CONSIDERATIONS:}

Mr. Justice Laycraft attempts to buttress his judgment in Rahn with three final assertions. First, his Lordship asserts, it would trivialize the Charter if every time a police officer kept an individual waiting, requested information, or came in contact with a citizen in the course of his duties he breached the individual's rights under the Charter. This of course, is not the situation in the Rahn case. The contact between the police of ficers and the accused was not a normal day to day occurence in the course of the officer's duties. Rather the contact occured in the course of investigating whether the accused had committed a crime and during the gathering of evidence for a successful prosecution against him. This is hardly the same as keeping an individual waiting for three minutes while cross-traffic proceeds. ${ }^{20}$

Mr. Justice Laycraft's second assertion is that the drafters of the Charter could only have intended that the individual be advised of his right to counsel where to do so might be of some use. Counsel would not be available at four o'clock in the morning on an Alberta roadside. ${ }^{21}$ The difficulty with this proposition is that not all breathalyzer demands are made at four o'clock in the morning on a remote Alberta roadside. Some are in fact made at times and at locations when counsel would be readily available, either in person or by telephone. More importantly, the practical difficulty in pursuing a right should not negate its existence.

Mr. Justice Laycraft final assertion is essentially that the duration of this type of "detention" is such that the remedy of habeas corpus, as provided for in section 10 (c) of the charter, is inappropriate. Thus, runs the logic this type of "detention" cannot be "detention" within the meaning of section 10 of the Charter. This, of course, is circular reasoning. The practical availability of one remedy for a violation of a Charter right can-

18. Id.

19. (1983) 32 C.R.(3d) 147 (Alta. C.A.).

20. Supran. 5 at 302.

21. Id. at 302-303. 
not determine the scope of the right itself. If habeas corpus is an impractical remedy here, the accused is still left with the plethora of remedies available under section 24(1) of the Charter or the possible exclusion of evidence pursuant to section $24(2) .{ }^{22}$

\section{CONCLUSION}

The decision in Rahn is in agreement with the judgements of the Nova Scotia Supreme Court (Appeal Division) in Regina v. Currie ${ }^{23}$ and the Newfoundland Court of Appeal in Regina v. Trask. ${ }^{24}$ However, the Saskatchewan Court of Appeal has given a contrary ruling in Regina v. Therens. ${ }^{25}$ Most recently, in Regina v. Simmons, ${ }^{26}$ the Ontario Court of Appeal agreed with the judgement in the Rahn case. The decisions in Campbell ${ }^{27}$ and Engen ${ }^{28}$ are essentially the same as that in the Rahn case. ${ }^{29}$ The meaning of "arrest or detention" in section 10 of the Charter and its impact on breathalyzer cases will clearly be settled by the Supreme Court of Canada. Given the number of persons who are asked to take breathalyzer tests, an early resolution of this matter would be desirable. When a decision is rendered on this issue we will have an important indication of the value of pre-Charter jurisprudence on Charter litigation.

22. Section 24 of the Charter provides:

(1) Anyone whose rights or freedoms, as guaranteed by this Charter, have been infringed or denied may apply to a court of competent jurisdiction to obtain such remedy as the court considers appropriate and just in the circumstances.

(2) Where, in proceedings under subsection (1), a court concludes that evidence was obtained in a manner that infringed or denied any rights or freedoms guaranteed by this Charter, the evidence shall be excluded if it is established that, having regard to all the circumstances, the admission of it in the proceedings would bring the administration of justice into disrepute.

23. (1983) 33 C.R. (3d) 227 (N.S.S.C.).

24. (1983) 6 C.C.C. (3d) 132 (N.C.A.). (Leave to appeal to the Supreme Court of Canada granted June 20, 1983.).

25. Supra n. 11.

26. (1984) 3 O.A.C. 1. Howland C.J.O. held that the word "detention" in section 10(b) of the Charter should be interpreted in the same manner as "detention" in section 2(c) of the Canadian Bill of Rights. (at 13 et seq.) Tarnapolsky J.A. in a carefully written dissenting judgement analyzed the previous jurisprudence and ultimately agreed with the majority decision of the Saskatchewan Court of Appeal in Therens, supra, n. 11 . (at 19 et seq.)

27. Supran. 7.

28. Supran. 6.

29. An interesting sidelight is the legality of the search in Engen, id.; Quaere, if the accused was not under arrest or in detention, from where did police of ficers derive their power to search his person? This matter was addressed in a cursory manner only at 29 A.L.R. (2d) 307, 50 A.R. 54 (Alta. C.A.). 